\title{
DIE SUID-AFRIKAANSE VLOOT: VERLEDE, HEDE EN TOEKOMS DEEL II
}

\author{
Wrn André Wessels*
}

Part Two of this article discusses the nature of the onslaught against South Africa, the probable needs of the South African Navy in the event of a multi-dimensional potential maritime attack on South Africa and draws a parallel between the different types of vessels and equipment we have and those that would be preferable in order to successfully avert the threat against the Republic of South Africa. He subsequently discusses the South African Coast Guard and maritime defence systems of the country and continues to examine the role of Indians and Coloureds in the South African Navy. South African harbours and dockyards and in particular the role of Walvis Bay are discussed.

The author concludes with the observation that we in South Africa should never forget that he who desires peace, should prepare for war.

\section{$\bigvee$. Toekomstige Ontwikkelinge: Moontlikhede en Probleme.}

\section{Die Aard van die Maritieme Aanslag teen Suid-Afrika.}

In meer as een opsig kan daar heeltemal tereg geredeneer word dat Suid-Afrika nie werklik van die see se kant bedreig word nie, dat ons in 'n oorlog van lae intensiteit aan die SWA-grens gewikkel is, met die moontlikheid dat nuwe fronte aan ons ander grense geopen kan word. Net soos wat dit dwaas sou wees om te redeneer dat Suid-Afrika hom tov die Leër slegs hoef in te stel op 'n terroriste-oorlog, so sou dit ook baie kortsigtig wees om te dink dat Suid-Afrika nie ook van die see se kant af direk of indirek gekonfronteer kan word nie. Hoewel die moontlikheid dat Suid-Afrika in 'n konvensionele seestryd betrokke sal raak baie skraal is, en so ook die moontlikheid dat die land deur 'n vyandelike vloot geblokkeer sal word, is dit moontlikhede wat nogtans teoreties - en dus ook as dit kom by vlootbeplanning - nie uitgesluit mag word nie.

'n Groter wesenlike gevaar is egter dié van 'n indirekte en/of onkonvensionele maritieme aanslag. Dit kan basies twee vorms aanneem:

(a) Toenemende Russiese (en in die jare wat kom ook Rooi Chinese) ${ }^{84}$ maritieme teenwoordigheid in die Indiese en Suid-Atlantiese Oseane, met vlootbasisse en/of ankergeriewe in hawens in aangrensende of nabygeleë lande en eilande, bv Angola, Mosambiek, Madagaskar, Mauritius en die Seychelles. Die teenwoordigheid van Russiese vaartuie tydens vlagvertoonreise maak 'n groot indruk (veral sielkundig) op die Swartmense, soveel te meer omdat die Weste tot 'n groot mate hulle plig in dié verband versuim. Hawens in genoemde lande kan ook gebruik word om militêre toerusting (insluitende pantsertuig) af te laai vir gebruik deur die vyande van Suid-Afrika teen die land. ${ }^{85}$

Indien daar volskaalse oorlog in Suider-Afrika sou uitbreek, moet Suid-Afrika in staat wees om oa die vyandelike seewaartse toevoerroetes af te sny. Hiervoor is duikbote en/of maritieme aanvalsvliegtuie en/of oppervlakte-skepe nodig. Vyandelike skepe moet $\mathrm{nl}$ onderskep en tot sink (of oorgawe) gebring word, vóórdat hulle hul bestemmings bereik. Die onderskepping moet ook, indien moontlik, op die diepsee, ver weg van die kus, maar ook ver genoeg vanaf die vyand se basisse af plaasvind, om inmenging of hulp aan sy kant te beperk.

(b) Daar kan verwag word dat see-terrorisme gaan toeneem. Dit kan ten minste drie vorms aanneem:

(i) Die kaping van vrag-, olietenk- ea skepe op die diepsee of langs ons kuste. Om dit te probeer voorkom is nodig dat daar aan boord van elke skip 'n klein goedopgeleide anti-terroriste groep is wat die skip kan bewaak en kan optree teen terroriste wat aan boord versteek is, of wat aan boord kom tydens die vaart, bv vanaf ander skepe, duikbote of 
dingies. Hulle moet veral ook in vreemde hawens die skip bewaak, en moet ook die skip kan deursoek sou 'n bomdreigement ontvang word. ${ }^{86}$ Skepe behoort ook met wapens toegerus te kan word sodat hulle hul in 'n sekere mate self kan beskerm, al is dit dan net met $20 \mathrm{~mm}$ kanonne, masjiengewere, antimissielstelsels en ligfakkels. $\mathrm{Vgl}$ dat sommige missiele baie klein en maklik hanteerbaar en installeerbaar is.$^{87}$

(ii) Vyandelike duikbote wat terroriste en/of uitrusting langs verlate kuste aflaai vir sabotasie ea terroristiese doeleindes. As teenmaatreël word maritieme verkenningsvliegtuie met duikbootjagwapens, duikboothelikopters en oorlogskepe benodig.

(iii) Hawens en hawestede gaan moontlik al hoe meer die teikens van terroriste word. Hawens kan natuurlik ook deur duikbote, wat bv skepe binne die hawe aanval of by die hawe-ingange voorlê, aangeval word. Ook kan duikbote of oorlogskepe hawestede en veral industriële gebiede en/of olie-opslagplekke bombardeer. Die grootste gevaar is egter dat terroriste $\mathrm{dmv}$ dwergduikbote of dingies, of as verstekelinge aan boord gewone skepe, hawens kan binnekom en dan sabotasie pleeg. In die digbeboude en relatief beknopte hawegebiede kan hulle groot skade aanbring en is teenoptrede baie moeilik. Dit is natuurlik ook moontlik dat terroriste van die land se kant teen hawens en skepe kan optree. Terroriste kan moontlik selfs skepe kelder sodra hulle ' $n$ hawe in-of uitgaan, en sodoende die hawe blokkeer. Vir teenoptrede teen terroriste in hawegebiede word patrollievaartuie vir patrolleerwerk en teenaanvalle binne en buite hawens benodig, asook gespesialiseerde kommando's of mariniers om in die hawens - op die water of in die dokgebiede - te opereer. Daar sal beslis onkonvensioneel opgetree moet word om die onkonvensionele aanslag teen ons af te weer.

Uit bg blyk dit dat Suid-Afrika met 'n baie omvattende en multi-dimensionele potensiële maritieme aanslag teen hom sit, en wat in die toekoms al hoe groter eise aan die Vloot gaan stel.

\section{Waaroor die Suid-Afrikaanse Vloot moontlik graag sou wou beskik het.}

Indien daar nie 'n wapenboikot teen Suid-Afrika was nie, sou die Suid-Afrikaanse Vloot vandag moontlik oor heel ander toerusting beskik het, en sou die Vloot, soos tot ongeveer 1970, moontlik steeds uitsluitlik oor Britsvervaardigde of -ontwerpte vaartuie bestaan uit. Dit is bv heel moontlik dat Suid-Afrika teen die einde van die sestiger- of begin sewentigerjare vier na ses Brits-ontwerpte fregatte, min of meer soortgelyk aan die Iranese Saam-klas van 1110 ton sou aangekoop het. ${ }^{88}$ Moontlik sou ook miskien drie Leander-klas ${ }^{89}$ fregatte van Brittanje aangekoop gewees het, of so nie, in die laat sewentigerjare van die Amazon-klas fregatte ${ }^{90}$ om die huidige drie President-klas fregatte te vervang of aan te vul. Die moontlikheid bestaan natuurlik ook dat sommige van hierdie skepe in Suid-Afrika gebou sou word. 'n Ander moontlikheid is dat SuidAfrika sy eie oorlogskepe sou ontwerp en gebou of laat bou het, maar dan met feitlik uitsluitlik Britse wapenstelsels ea toerusting aanboord.

Die President-klas fregatte sou heel moontlik ook tydens hul modernisering met addisionele Britse wapentuig - bv Seacat see-tot-lug-missiele toegerus gewees het. Ook sou ons mynveërs miskien vroeër reeds in mynjagters omskep gewees het, en sou teen hierdie tyd reeds bestellings geplaas gewees het vir ten minste tien Hunt-klas mynjagters. ${ }^{91}$ Suid-Afrika sou miskien ook liewer die groter Oberon-klas duikbote ${ }^{92}$ wou aangeskaf het ipv die Daphne-klas, en sou teen hierdie tyd moontlik ook ' $n$ bestelling vir nog méér duikbote by Brittanje geplaas het. Aan die ander kant is die Daphne-klas uitstekende duikbote en ideaal geskik vir die Suid-Afrikaanse Vloot se behoeftes.

Ons maritieme lugarm sou moontlik ook reeds oor ten minste agt Britse Nimrod-verkenningsvliegtuie ${ }^{93}$ en Lynx- en/of Sea King-helikopters ${ }^{95}$ beskik het, terwyl 'n bestelling vir Tornado-multi-doel-vliegtuie ook nie uitgesluit sou gewees het nie. ${ }^{96} \mathrm{Al}$ bg moontlikhede dui daarop dat enersyds die Suid-Afrikaanse Vloot vandag sterker daaraan toe sou gewees het indien Brittanje nie aan die wapenboikot deelgeneem het nie, en andersyds dat Brittanje deur die jare heen baie geld en werkgeleenthede verloor het deur nie wapens aan Suid-Afrika te verskaf nie.

As alternatief vir Britse wapentuig sou Suid-Afrika miskien ook graag bv Franse Atlantic- ${ }^{-7}$ of 
Amerikaanse Orion-verkenningsvliegtuie ${ }^{98}$ wou gekoop het. Tien Franse Eridan-klas mynjagters ${ }^{99}$ sou ook goed te pas gekom het, en so ook twee of meer Franse Agosta- of Italiaanse Sauro-klas duikbote. ${ }^{100}$

Suid-Afrika se maritieme behoeftes en die alternatiewe oop onder die huidige wapenboikot kan moontlik as volg saamgevat word: 101

\section{(1) Fregatte.}

Die drie President-klas fregatte sal binne ongeveer tien jaar verouder wees. Hulle sou vir die huidige verder gemoderniseer kon word en bv met Gabriel-see-tot-see-missiele en Aspide- of Cactua-see-tot-lug-missiele toegerus word. In die lig van hulle beperkte aantal oorblywende diensjare sal dit egter moontlik onekonomies wees.

Indien hulle oor 'n periode van tyd vervang moet word, sou die logiese plaasvervangers (vir die huidige altans) drie of meer Britse Amazon- of Italiaanse Lupo-klas fregatte ${ }^{102}$ wees. Veral Ig is ' $n$ klein dog uiters kompakte en goed bewapende veeldoelige fregat. 'n Ander moontlikheid is ten minste ses Franse Tipe 69-, Spaanse F30-, ${ }^{103}$ NAVO Tipe 122-104 of Israelse fregatte. Die Franse fregatte is ons geweier, en dit is redelik onwaarskynlik dat Spanje ons van wapens sal voorsien. Daar is egter sprake dat Suid-Afrika moontlik ses Israelse fregatte van 850 ton elk en toegerus met $2 \times 76 \mathrm{~m}$ en $4 \times 30 \mathrm{~mm}$ kanonne, 4 Gabriel- (of Harpoon-) missiele, ses torpedobuise en $2 \times 75 \mathrm{~mm}$ Boforst duikbootjagmortiere asook ' $n$ helikopter, gaan bou of aankoop. ${ }^{105} \mathrm{Lg}$ skepe is uiters geskik vir ons behoeftes.

Suid-Afrika kan natuurlik ook sy eie fregatte of korvette ontwerp en bou. ' $n$ Moontlikheid sou bv wees 'n skip van ongeveer 1000 1400 ton, toegerus met bv $1 \times 76 \mathrm{~mm}, 4 \times 40$ $\mathrm{mm}$ en $2 \times 20 \mathrm{~mm}$ kanonne, vier Gabrielmissiele, ses duikbootjagtorpedobuise, $2 x$ $375 \mathrm{~mm}$ duikbootjagmortiere, 'n Corvexmissielafweerstelsel, ' $n$ agtvoudige Aspideof Crotale- see-tot-lug-missielstelsel, en 'n Lynx helikopter ${ }^{106}$ Daar is natuurlik ook ander moontlikhede tov die bewapening.

Wat Suid-Afrika eintlik benodig is Amerikaanse Spruance-klas torpedojaers, ${ }^{107}$ maar agv hulle grootte en die groot bemannings wat hulle benodig, sou dit - selfs al sou ons hulle kon bekom - 'n onrealistiese keuse wees.

\section{(2) Duikbote.}

Die huidige drie Daphne-klas duikbote is eintlik slegs vir opleiding en patrollering bedoel. Suid-Afrika sou miskien liewer Britse Oberon- of so nie Franse Agosta- of Italiaanse Sauro-klas duikbote wou gehad het, of moontlik ook die nuwe Britse tipe konvensionele duikboot wat tans beplan word. Suid-Afrika moet $\mathrm{nl}$ in staat wees om vyandelike skepe en duikbote ver van die Suid-Afrikaanse kus af op die diepsee te onderskep, aan te val en te vernietig.

\section{(3) Patrollievaartuie.}

Die huidige vinnige missieldraende patrolliebote kan nog vir baie jare lank diens doen.

Siende dat ons blykbaar niks ander kan bekom nie, is dit beslis nodig dat meer van hierdie vaartuie bekom moet word. ${ }^{108}$ Eintlik behoort die wapentuig van toekomstige vaartuie van dié klas gewysig te word, sodat hulle ' $n$ beter duikbootjagvermoë sal hê. So bv behoort ipv die missiele en $1 \times 76 \mathrm{~mm}$ kanon op die agterdek, ' $n$ helikopterlandingsplatform daar aangebring word, en moontlik ook 'n teleskopies of konsertinatipe helikopterloods om beskerming aan die helikopter te bied. Die ideaal sou natuurlik wees om 'n Lynx- of Augusta-helikopter ${ }^{109}$ te gebruik ipv die ietwat verouderde Wasps.

'n Dubbelloop $375 \mathrm{~mm}$ duikbootjagmortier kan natuurlik ook agterop gemonteer word, maar dit is nie duidelik of dié wapen bekom kan word nie. As alternatief kan 'n veelvoudige Bofors-vuurpyllanseerder of miskien selfs plaaslikontwerpte variant, ook van waarde wees. So nie moet die vaartuie maar met twee drieloop duikbootjagtorpedobuise toegerus word. In watter mate die vaartuie oor duikbootopsporingsapparaat (sonar) beskik of toegerus kan word, is onbekend. Dit help nl nie veel dat 'n vaartuig in staat is om 'n duikboot te vernietig, maar dit nie kan opspoor nie.

Om die lugafweervermoë van die aanvalsvaartuie te verhoog, kan daar 'n $2 \times 40 \mathrm{~mm}$ Italiaanse Breda-lugafweerkanon ipv die agterste $76 \mathrm{~mm}$ kanon gemonteer word. Die ideaal sou natuurlik wees om die agtvoudige Franse skeepsmodel van die Cactus-grond- 
tot-lug-missiel óf die Italiaanse Aspidemissielstelsel agterop te monteer, mits dit natuurlik moontlik sou wees. Die viervoudige Cactus kan moontlik ook vir skeepsdoeleindes aangepas word.

Dit sou vanselfsprekend beter gewees het indien ' $n$ ietwat groter tipe aanvalsvaartuig gebou kon gewees het. Die ideaal sou wees ' $n$ vaartuig van sowat 500 ton met $1 \times 76 \mathrm{~mm}$, $2 \times 230 \mathrm{~mm}$ en $2 \times 20 \mathrm{~mm}$ kanonne, $2 \times 12,7$ $\mathrm{mm}$ masjiengewere, vier Gabriel of Harpoonmissiele en 'n Lynx-helikopter met 'n helikopterloods. ${ }^{110}$ Miskien sou duikbootjagtorpedobuise en/of -mortiere ook monteer kon word.

Wat haweverdediging aanbetref, is die klein Namacurra-haweverdedigingsvaartuie goed geskik vir hul taak, hoewel daar eintlik ten minste 50 gebou behoort te word, sodat daar meer van hulle in elk van Suid-Afrika se nege hawens (insluitende Simonstad) ontplooi kan word. Miskien behoort 'n aantal groter bote ook gebou te word, toegerus met een of twee $20 \mathrm{~mm}$ kanonne, wat met groter gemak ook buite hawe-ingange en naby die kus aangewend sal kan word.

\section{(4) Mynjagters.}

Op die oomblik het Suid-Afrika blykbaar slegs twee mynveërs en twee mynjagters, aangesien die ander ses kusmynveërs in patrolliebote (met beperkte mynveevermoëns) omskep is.

Die ideaal sou gewees het indien ten minste tien Britse Hunt- of Frans-NederlandsBelgiese Eridan-klas mynjagters aangekoop kon word. Die gevaar is $\mathrm{nl}$ groot dat vyandelike skepe, maar veral duikbote, seemyne om ons kuste kan lê of selfs by hawe-ingange of in hawens self $-\mathrm{lg}$ deur see-terroriste.

Indien Suid-Afrika nie oorsese bystand op die gebied van mynbestryding kry nie, sal ons noodgedwonge self iets moet improviseer. Moontlik is ons wel in staat om die skepe as sodanig te bou. 'n Veselglas romp (soos dié van die Britse Hunt-klas) is natuurlik die ideaal. ' $n$ Ander moontlikheid is natuurlik om seemyne dmv helikopters op te spoor, soos wat die Amerikaners doen, maar dit is onwaarskynlik dat hulle ons van dié tipe helikopters sal voorsien.

\section{(5) Ondersteuningsvaartuie.}

(a) Opmetingsvaartuie - Die Protea kan nog baie jare lank diens doen. Die Haerlem sal egter binne 'n paar jaar vervang moet word. ' $n$ Vaartuig kan vir dié doel in Suid-Afrika gebou word. Indien die Protea oor sowat vyftien jaar of langer uitgedien is, behoort ' $n$ plaasvervanger ook in Suid-Afrika gebou te kan word.

(b) Vlootaanvullingskepe - Indien die drie fregatte geskrap word en nie vervang word nie, sal die Tafelberg geen rol meer te vervul hê nie. Hoewel nog bruikbaar op die huidige stadium, is die skip reeds redelik oud. Sou nuwe fregatte wel bekom word, behoort die Tafelberg behou te word, aangesien dit die operasionele trefradius van die fregatte vergroot. Miskien is Suid-Afrika skeepserwe later so ontwikkel dat hulle een of twee (moontlik effens kleiner) plaasvervangers vir die Tafelberg kan bou.

(c) Torpedo-herwinningsvaartuie Hierdie vaartuie kan na willekeur in Suid-Afrika gebou word.

(d) Sperboomvaartuie - Hoe lank die 38 jaar oue Somerset nog sal kan diens doen, is onbekend. Moontlik kan sulke tipe vaartuie in Suid-Afrika gebou word. Daar behoort veiligheidshalwe twee sperboomvaartuie in die Vloot te wees.

(e) Reddingsvaartuie - Hierdie tipe vaartuie kan in Suid-Afrika gebou word. In die lig van die druk skeepsverkeer om ons kuste en die moontlikheid van rampe, behoort ten minste tien van hierdie tipe vaartuie gebou te word en by die onderskeie hawens gestasioneer word. Indien Suid-Afrika 'n kuswag sou bekom, 111 sal hierdie vaartuie daaronder ressorteer.

(f) Sleepbote - Kan na willekeur in Suid-Afrika gebou word.

Noudat die toekomstige ontwikkelinge tov die Vloot as sodanig in oënskou geneem is, moet daar ook kortliks na die toekomstige moontlikhede en probleme van die maritieme lugarm gekyk word. 
Daar sou geredeneer kon word dat dit meer ekonomies is (ook itv mannekrag) om eerder op die lugmag staat te maak om ons kuste te patrolleer. Ongelukkig is dit egter juis so dat dit veral die maritieme arm van die Lugmag is waar daar tans reeds groot tekortkominge is, en in die toekoms ook nog groter probleme kan ontstaan. Die onderskeie tipes vliegtuie wat vir maritieme verdediging noodsaaklik is, word nou kortliks in toekomsperspektief geplaas:

\section{(i) Maritieme Onderskeppingsvliegtuie.}

Op die oomblik wil dit nie voorkom of die huidige Buccaneers - in die lig van die wapenboikot - maklik vervang sal kan word nie. Eintlik benodig Suid-Afrika sowat 50 Amerikaanse Phantoms, ${ }^{112}$ F-14 Tomcats ${ }^{113}$ of Brits-Duits-Italiaanse Tornado's. Indien Suid-Afrika geen maritieme aanvalsvliegtuie meer het nie, sal dit ons vermoë om vyandelike skepe ver van ons kuste af te onderskep, aan te val en te vernietig, baie kortwiek.

\section{(ii) Maritieme verkenningsvliegtuie.}

Die sewe Shackletons se dae is in meer as een opsig reeds getel, en dit is net die Lugmag se tegniese kundigheid wat hulle nog in die lug hou. Hulle is egter onvoldoende vir langafstand-verkenning oor groot gebiede. ( $\mathrm{Vgl}$ bv die soektog na die Berge Wanga). Suid-Afrika benodig eintlik ten minste agt Nimrods, Atlantics of Orions, maar weens die wapenboikot is dit onwaarskynlik dat hulle bekom sal kan word. Boonop is die Albatros-verkenningsvliegtuig (waarvan ons sewentien het) slegs vir relatief kortafstandverkenning geskik.

'n Moontlike oplossing is om gewone passasiers- of vragvliegtuie aan te koop en dan so goed moontlik in maritieme verkenningsvliegtuie te omskep. $\mathrm{Vgl}$ bv die Britse HS $748^{114}$ of Israelse Arava wat geskik is vir dié doel. Ook kan die Lockheed Hercules $\mathrm{C}-130$, of as hulle nie bekom kan word nie, die kommersiële model, $\mathrm{nl}$ die L100-30, omskep word. ${ }^{115}$ Deur addisionele brandstoftenks aan te heg kan die vliegradius van hierdie vliegtuie ook aansienlik verhoog word.

\section{(iii) Helikopters.}

Suid-Afrika benodig veral helikopters vir duikbootjagdoeleindes. Dit is egter te betwy- fel of die Wasps se logiese onvolgers, die Lynx of Augusta-Beel, aangekoop sal kan word. Tydens die Verdedigingsbegroting se bespreking in 1979 het die Eerste Minister bekend gemaak dat Suid-Afrika selfvoorsienend is tov helikopters. Daar kan maar net gehoop word dat Suid-Afrika ook in staat sal wees om binne afsienbare tyd helikopters vir maritieme verkenning, redding en duikbootjag te kan bou.

Uit alles wat oor die toekomstige moontlikhede en probleme van die Suid-Afrikaanse Vloot (en maritieme lugarm) gesê is, blyk dit dat, indien die wapenboikot nie gelig, verslap of omseil kan word nie, die land in die toekoms probleme op vlootgebied kan verwag. Aan die ander kant is ons wel gelukkig genoeg om sekere tipes skepe en wapens self te kan vervaardig. Ironies genoeg het die wapenboikot ons $\mathrm{nl}$ tot 'n groot mate (hoewel alles behalwe heeltemal) selfvoorsienend gemaak.

\section{Die moontlike aanwending van Handelsvaartuie in oorlogstyd, en die beskerming van Handelsvaartuie in die algemeen.}

' $n$ Saak waaraan aandag gegee behoort te word is die beskerming van handelsvaartuie (in hierdie geval dan spesifiek Suid-Afrikaanse skepe) op alle reise wat hulle onderneem. ' $n$ Skip is $\mathrm{nl}$ ' $\mathrm{n}$ maklike teiken vir see-terroriste. Dus behoort 'n klein groepie gespesialiseerde mariniers of see-kommando's aan boord elke skip te wees, of behoort lede van die bemanning opleiding te ondergaan, sodat hulle die skip kan beskerm. Daar behoort egter ook aan boord skepe die nodige ruimte en fasiliteite te wees waar ligte kanonne (bv $20 \mathrm{~mm}$ ) of masjiengewere (bv 12,7 $\mathrm{mm}$ en 7,62 mm) maklik geïnstalleer kan word. $\mathrm{Vg} \mid \mathrm{nl}$ dat tydens die Tweede Wêreldoorlog die meeste Suid-Afrikaanse oorlogskepe omgeboude treilers of walvisjagters was. ${ }^{116}$

Wanneer handelskepe gebou of laat bou word, behoort ook daaraan gedink word om die skepe so te ontwerp dat hulle binne 'n kort tyd en sonder veel moeite of onkoste met wapentuig toegerus kan word. Indien hierdie vinnige omskeppings moontlik is, sal hulle $\mathrm{nl}$ hulself relatief gesproke kan verdedig in oorlogstyd en sal dit miskien nie eens nodig wees om hulle in konvooie te laat vaar of voortdurend oorlogskepe as begeleidingskepe saam te stuur nie. So bv behoort $76 \mathrm{~mm}, 40 \mathrm{~mm}$, $35 \mathrm{~mm}$ en/of $20 \mathrm{~mm}$ kanonne en $12,7 \mathrm{~mm}$ of 7,62 $\mathrm{mm}$ masjiengewere gemonteer te word, en 


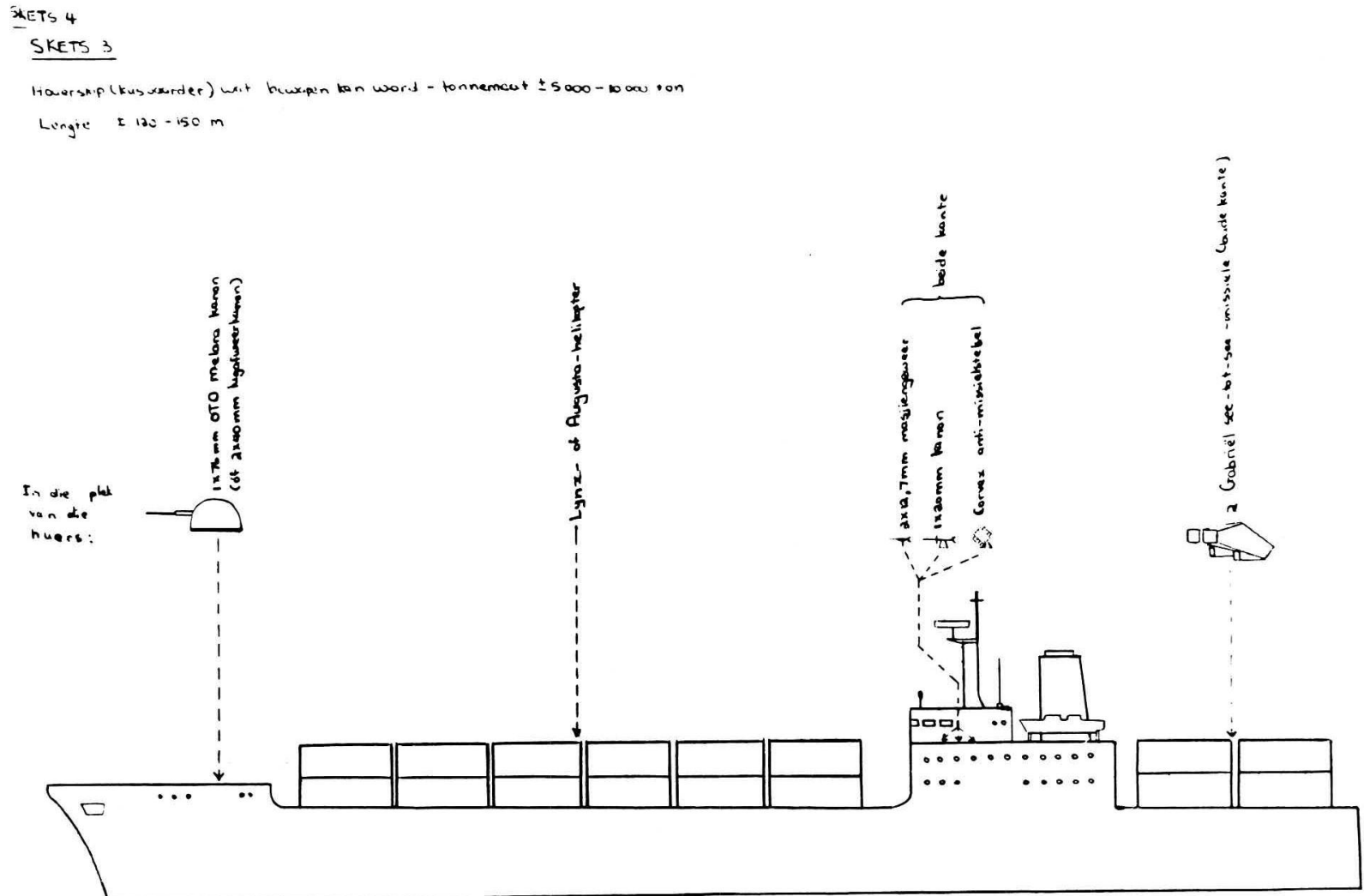

moontlik selfs see-tot-see en see-tot-lugmissiele, asook anti-missiel stelsel en bv duikbootjagtorpedobuise. Daar behoort ook iewers op die dek 'n groot genoeg gelyk oppervlakte beskikbaar te wees wat as landingsplatform vir 'n helikopter gebruik kan word. ${ }^{117}$

Die moontlikheid dat gewone handelsvaartuie met wapens toegerus kan word open interessante alternatiewe in die lig van die wapenboikot en Suid-Afrika se mannekragprobleem. Die moontlikheid bestaan $\mathrm{nl}$ nou dat handelsvaartuie gebou kan word met as einddoel om hulle as oorlogskepe aan te wend. Handelsvaartuie is immers al in Durban gebou, en daar behoort nie in die toekoms probleme te wees om nog meer te bou nie. Vlootbeplanners kan nou saam met Suid-Afrikaanse handelsvlootmaatskappye beplan om handelskepe te laat bou met die oog daarop om, sou dit nodig wees, hulle op kort kennisgewing in oorlogskepe te omskep. Die handelskeepslui kan dan steeds gebruik word om die skepe te beman, terwyl vlootpersoneel slegs by die bemanning toegevoeg sal word om die wapens te bedien. Dit sal dus nie vir die Vloot nodig wees om veel meer personeel op te lei nie.

Enige sodanige samewerking tussen die Vloot en handelsvlootmaatskappye moet vanselfsprekend uiters geheim wees, en so ook die beplanning en uiteindelik doel van die skepe. Die konstruksie en te water lating sal gewone publisiteit mag geniet, maar die potensiële 'ekstras' op die skepe moet uiters geheim gehou word. 'n Mens sal natuurlik ook daarteen moet waak dat mens nie hier (en oorsee) die snuf in die neus kry deurdat bv té veel van dieselfde tipe skip gebou word nie.

\section{4. 'n Suid-Afrikaanse Kuswag}

'n Aangeleentheid waaraan daar in die toekoms ernstige aandag gegee behoort te word is die daarstelling van 'n Suid-Afrikaanse Kuswag. Die Suid-Afrikaanse Vloot is verantwoordelik vir die beskerming van ons kuste, met alles wat dít impliseer. Met die nuwe vlootbeleid en die terugtrekking (by wyse van spreke) van die Vloot na ons gebiedswater en dus tot naby ons kus, is die rol van die Vloot (blykbaar) al hoe meer dié van 'n (blote) kuswag. Selfs hierdie (relatief 
beperkte) taak van die Suid-Afrikaanse Vloot is egter agv oa ons lang kuslyn en die baie skepe wat om die Kaap vaar, 'n gewigtige een.

Hou ' $n$ mens in gedagte dat daar ook talle vissersen plesierbote om ons kuste vaar en dat van hulle in die moeilikheid raak, dan word die omvang van die probleem des te duideliker, en soveel te meer ook nog wanneer gelet word op hoe klein die Nasionale Seereddingsinstituut (NSRI) - wat tans seeredding om ons kuste moet doen werklik is. Hulle het $n l$ relatief gesproke baie min en baie klein vaartuie, en hulle ondervind finansiële probleme om nuwe en groter vaartuie aan te skaf. $\mathrm{Vgl}$ bv die probleem rondom die verouderde John Ross wat in Durban gestasioneer is.

Indien 'n kuswag in Suid-Afrika op die been gebring kan word, min of meer iets soos die Amerikaanse Kuswag, hoewel vanselfsprekend nie so groot nie, en die nodige geld van staatsweë beskikbaar gestel kan word, sal ons vir enige tipe seeramp of noodsituasie voorbereid wees. Die NSRI lewer met hulle beperkte middels en onder moeilike omstandighede uitstekende dienste. 'n Mens is egter net bang dat in 'n ware groot krisissituasie daar weens 'n gebrek aan goeie (en veral diepsee-) reddingsbote toegekyk sal moet word hoedat lewens wat gered kon gewees het, verlore gaan.

'n Goed georganiseerde en toegeruste kuswag kan ook behulpsaam wees met die patrollering van ons kuste, veral ons viswaters. Daar is nl talle vreemde (bv Kommunistiese) visserbote en visverwerkingskepe om ons kuste bedrywig, en heel moontlik word hulle ook vir spioenasiedoeleindes gebruik.

Kuswagvaartuie hoef nie so gesofistikeerd te wees as oorlogskepe nie, en is ook kleiner en dus goedkoper en makliker om te bou. Tog kan hulle uiters doeltreffend aangewend word. ${ }^{118}$ Die kuswagskepe kan deur vrywilligers, vaste kuswagpersoneel en/of Vlootreserwelede (wat daarvoor opgeroep word) beman word. Moontlik kan ook van heelwat Bruin-, Indiër en Swartbemanningslede gebruik gemaak word. In tye van oorlog kan 'n para-militêre kuswag vanselfsprekend van groot waarde wees, en miskien selfs operasioneel aangewend word - afgesien van die feit dat die kuswag in oorlogstyd met reddings- en anti-besoedelingswerk besig sal wees.
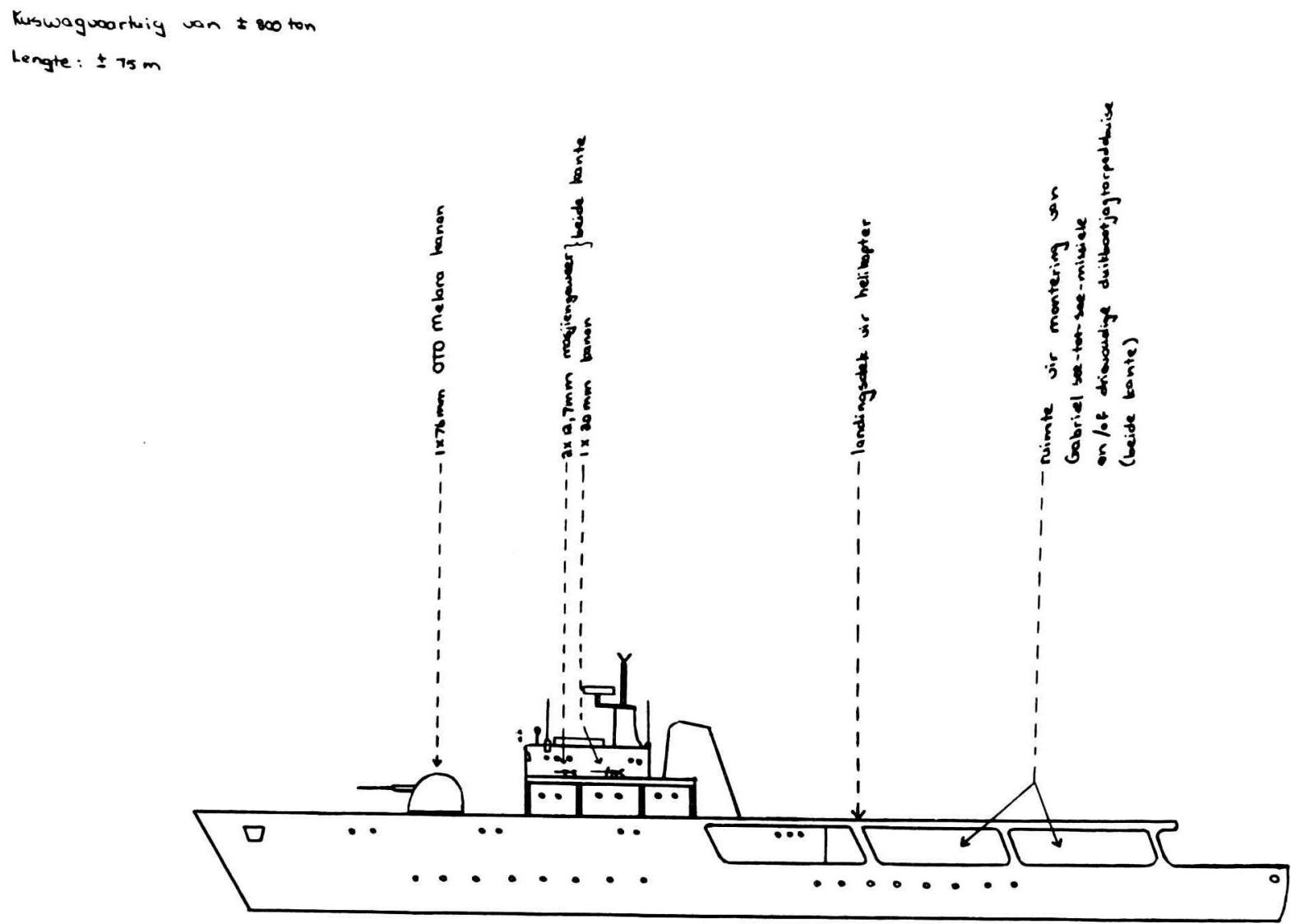
'n Saak wat ten nouste met 'n kuswag saamhang, is die bestryding van besoedeling. Die Kaapse seeroete is op die oomblik en ook in die toekoms die hoofslagaar van die Weste se olietoevoer. Tot dusver was Suid-Afrika baie gelukkig dat op twee na daar nog nie rampe aan ons kus was wat tot grootskaalse oliebesoedeling van ons kuste gelei het nie. Tog kan die moontlikheid van groot rampe met gepaardgaande besoedeling nie uitgesluit word nie, en so ook nie die moontlikheid van kapings en/of sabotasie van groot olietenkskepe om ons kuste nie. Geruime tyd reeds is daar vyf klein plaaslik-geboude oliebesoedelingsvaartuie - wat nie onder die Vloot val nie - aan diens om, in geval van oliebesoedeling, uit te vaar en oplosmiddels op die olie te spuit. Hoewel die feit dat daar wel sulke vaartuie bestaan en hulle in die verlede al gehelp het om besoedeling te bekamp, beter is as niks, is dit 'n ope vraag in watter mate hulle sukses kan waarborg, veral in gevalle van stormweer en/of waar daar meer as een ramp tegelyk plaas vind. Die bestaande vyf vaartuie, asook groter en moontlik moderner toegeruste vaartuie, behoort ook onder 'n kuswag te ressorteer.

\section{Maritieme Verdedigingstelsels aan Land.}

Oor die Mariniers se vermoë om ons hawens te beskerm, behoort daar geen twyfel te bestaan nie. Tog blyk ons hawens blootgestel aan vyandelike oorlogskepe en duikbote wat van ver af die kus of stede met kanonne en/of missiele kan bestook. Die vanselfsprekende teenaksie sou wees om skepe en vliegtuie uit te stuur om hulle te onderskep. Sulke optrede sal egter tot gevegte tussen die onderskeppende eenhede en die aanvallers lei, en die verdedigers kan dus self ook verliese ly.

Die vraag ontstaan dus of dit nie miskien makliker (en itv verliese goedkoper) sou wees om van wapenstelsels wat vanaf die land aangewend kan word, gebruik te maak nie. Hier dink 'n mens bv aan die viervoudige Franse Exocet MM40 grond-tot-see-missiel, ${ }^{119}$ 'n variant van die uiters doeltreffende en gewilde Exocet MM38 see-totsee-missiel, wat bv agterop 'n vragmotor gemonteer kan word. Die feit dat die MM40 vanaf die land aangewend kan word maak dit ook baie meer ekonomies, want dit benodig nie 'n (duur) skip as lanseerplatform nie, maar is steeds mobiel wanneer dit op 'n vragmotor gemonteer is. Hierdie stelsel kan ook in beton-bunkers gemonteer word, of so nie kan die voertuig wat dit dra òf self in ' $n$ bunker beskerm word, òf in bosse gekamoefleer word. Dit is dus beslis 'n moeiliker teiken as bv 'n skip om deur die aanvaller opgespoor en getref te word.

Naas grond-tot-see-missielstelsels kan kanonne in kusbatterye natuurlik ook teen oppervlaktevaartuie aangewend word. Outomatiese Amerikaanse $127 \mathrm{~mm}$, Britse $115 \mathrm{~mm}$, Franse $100 \mathrm{~mm}$ kanonne, wat gewoonlik op skepe gemonteer word, kan dus ook in kusbatterye naby haweingange of sleutelpunte wat aan die kus geleë is, gebruik word. Kusartillerie speel natuurlik altyd 'n komplimentêre rol saam met lugafweerkanonne en -missiele, bv $35 \mathrm{~mm}$ en $40 \mathrm{~mm}$ lugafweerkanonne en bv Roland, Cactus en Hawk grond-totlug-missiele.

By hawe-ingange behoort daar ook antiduikbootnette te wees, verkieslik geëlektrifiseer, wat terselfdertyd ook beskerming teen vyandelike dwergduikbote en paddamanne bied. Duikbootjagtorpedobuise en -dieptebomme behoort ook by hawe-ingange monteer te word.

Wapenstelsels wat vanaf die land opereer mag natuurlik nooit skepe en vliegtuie vervang nie. Dus moet daar gesorg word dat daar te alle tye 'n doeltreffende see- en lug-reaksiemag gereed staan, insluitende duikbootjaghelikopters.

\section{Die Rol van Indiërs en Bruinmense in die Suid-Afrikaanse Vloot.}

Dit is onregverdig om te verwag dat alleenlik Blankes vir die verdediging van Suid-Afrika verantwoordelik moet wees. Naas die feit dat alle inwoners van Suid-Afrika 'n verantwoordelikheid in hierdie verband het, ongeag ras, kleur, geloof of politieke oortuigings, sit die Blankes in elk geval in eie geledere met 'n mannekragtekort.

Nadat Bruin Suid-Afrikaners reeds vanaf 1966 in die Vloot diens doen, word Indiër Suid-Afrikaners die afgelope paar jaar by die Vlootopleidingsentrum SAS Jalsena in Durban opgelei. Soos in die geval van Bruinmense, geskied hierdie opleiding op 'n vrywillige grondslag. Soos wat daar al hoe groter eise aan die Vloot gestel gaan word, bestaan daar die moontlikheid dat daar in die toekoms al hoe meer Bruin- en Indiërmense in die Vloot opgeneem sal word. Harmonieuse samewerking op militêre gebied is seer sekerlik een van die beste maniere om goeie volkereverhoudinge in Suid-Afrika te bevorder, iets wat vir die toekoms van Suid-Afrika, ook vanuit militêre oogpunt gesien, onontbeerlik is. In watter mate Swartmense miskien ook later in die Vloot sal 
dien, is 'n ope vraag. ${ }^{120}$

\section{Suid-Afrika se Hawens en Skeeps- werwe.}

Suid-Afrika is gelukkig dat hy oor nege goed ontwikkelde en redelik goed gespasieerde hawens beskik, insluitende 'n baie doeltreffende vlootbasis te Simonstad en 'n kleiner dog ook handige basis in die Durbanse hawe, $\mathrm{nl}$ Salisbury-eiland. In elk van die gewone hawens is daar 'n vlooteenheid op land gestasioneer, en kan daar dus ook vlootskepe gestasioneer word. Dit is egter beter om (soos tans) die meeste skepe in Simonstad (die oorgrote meerderheid) en in Durban te konsentreer, waar daar goeie geriewe is, en vanwaar daar dan geopereer kan word.

Met die opening van die hawe te Richardsbaai het Suid-Afrika nou ook 'n 'maritieme venster' op Mosambiek, - naby genoeg van Ig om vinnig op te tree indien dit sou nodig wees, maar ook nié so naby dat dit maklik deur enige vyandelike mag onder skoot gekry of oorrompel kan word nie. Ongelukkig is die weskus noord van Saldanhabaai nie van 'n goeie hawe voorsien nie, en moet skepe redelik ver weg vanaf Simonstad vaar om patrollering te doen. Verder op langs die weskus kan patrolliewerk noord- en suidwaarts vanaf Walvisbaai gedoen word, al is die afstande wat gedek moet word baie groot.

Haweverdedigingsbote word (of gaan binnekort) in al die hawens ontplooi word. Daarbenewens behoort een of twee aanvalsvaartuie en mynveërs ook in Walvisbaai, en miskien ook in Richardsbaai, gestasioneer te word.

Soos tans reeds naby bv Kaapstad, Durban en Port Elizabeth die geval is, behoort vliegtuie en helikopters ook op ander plekke naby die kus gestasioneer te word vir patrollering en seeredding.

In Durban is daar geruime tyd reeds skeepswerwe, en daar kan maar net gehoop word dat hulle in die jare wat kom selfs meer as vandag nog in staat sal wees om in Suid-Afrika se maritieme skeepsbehoeftes te voorsien.

Met die wete dat die opleiding in die Vloot van die hoogste gehalte is, dat ons in staat is om tot 'n groot mate in one eie behoeftes te voorsien, die nodige kundigheid het om skepe self te onderhou en te herstel, kan die toekoms - te midde van sekere ernstige probleme en tekortkominge tog met vertroue tegemoet gegaan word.

\section{Die Rol van Walvisbaai.}

Van al Suid-Afrika se hawens is dit vandag veral Walvisbaai wat spesiale aandag verdien. Histories gesien is Walvisbaai sonder enige twyfel deel van die Republiek van Suid-Afrika, en nie van Suidwes-Afrika nie. Afgesien van die sekondêre ekonomiese ea oorweegredes, is dit van primêre militêr-strategiese belang dat Walvisbaai deel van die RSA sal bly.

Vanuit 'n Leër- en Lugmagoogpunt gesien is Walvisbaai 'n poort tot Suidwes-Afrika. Vanuit die Vloot se oogpunt behoort Walvisbaai beskou te word as 'n natuurlike verlengstuk van Suid-Afrika se seewaartse verdedigingsnetwerk. Indien met die nodige radar- en radiostelsels toegerus, kan skeeps- en vliegtuigbewegings oor ' $n$ gedeelte van die Suid-Atlantiese Oseaan $\mathrm{nl}$ van daar af gemonitor word. Indien maritieme verkenningsvliegtuie en oorlogskepe in Walvisbaai gestasioneer word, kan groot dele van die Suid-Atlantiese Oseaan ook fisies gepatrolleer word.

Op die oomblik is Russiese vlootbedrywighede in die Suid-Atlantiese Oseaan beperk, maar dit sou $d$ waas wees om te redeneer dat die Russe (en op die langeduur ook die Rooi Chinese) nie daarin belangstel om hulle invloed ook in dié gebied uit te brei nie. $\mathrm{Vgl}$ ook dat die hawens Lobito, Benguela en Luanda potensiële vyandelike vlootbasisse is, om nie eens te praat van lande en hawens verder op teen die Weskus van Afrika nie.

Met die Russe wat reeds tot ' $n$ groot mate in die Indiese Oseaan en aan die Ooskus van Afrika ingegrawe (of moet ons sê geanker!) is, sal 'n houvas op die Suid-Atlantiese Oseaan beteken dat hulle 'n kynptang-wurggreep op die Kaapse seeroete (en op Suid-Afrika) sal kan uitvoer.

Hoewel die VSA nav die Iranese-debakel uiteindelik tot 'n mate wakkergeskrik het en vir die eerste keer in baie jare ' $n$ redelike vlootteenwoordigheid in die Arabiese See en die Indiese Oseaan handhaaf, bly die Weste steeds te afsydig tov die veiligheid van die Kaapse seeroete, en laat dit - ironies genoeg! - oor in die hande van die Suid-Afrikaanse Vloot om te beskerm. ${ }^{121}$

In die Suid-Atlantiese Oseaan is daar vir alle praktiese doeleindes geen Westerse oorlogskepe op 'n permanente grondslag teenwoordig nie al het sekere NAVO-vlootoffisiere al teen hierdie laksheid gewaarsku. In die lig van die SuidAtlantiese Oseaan as 'n potensiële konflikgebied en Suid-Afrika se noodgedwonge betrokkenheid 
daarby, kan en mag die militêr-strategiese belangrikheid van Walvisbaai nooit onderskat word nie.

\section{Slot}

In die stryd tussen die magte van die Lig en die magte van die Duisternis tussen die Civitas Dei en die Civitas Terenna, die voorstanders van demokrasie en die Kommuniste, moet daar definitiewe keuses gemaak en standpunt ingeneem word. Geen land en geen individu mag selfs eers poog om afsydig te staan teenoor hierdie ideologiese en beginselstryd nie.

Waar Suid-Afrika nie vroeër in die kalklig van die internasionale politiek was nie, is hy veral ná die Tweede Wêreldoorlog al hoe meer by die subtiele magspolitiek van die Koue Oorlog ${ }^{130}$ en alles wat met lg gepaard gaan, betrek. Die stygende belangrikheid van Suid-Afrika se geografiese ligging, die Kaapse seeroete en die land se minerale rykdomme, gekoppel aan die rassevraagstuk, die opkoms van Swart nasionalisme en die gevolge daarvan, asook die verwikkeling in Suidelike Afrika in die algemeen, maak SuidAfrika enersyds al hoe meer ' $n$ brandpunt in internasionale politiek en andersyds ' $n$ meer gesogte teiken.

In die lig van die groeiende totale aanslag teen die land, insluitende die wapenboikot, en die feit dat wapentuig vandag agv die geweldige tegnologiese ontwikkelingstempo gouer as vroeër uitgedien raak, ${ }^{131}$ word die verdediging van Suid-Afrika - veral tov sy Vloot - al hoe moeiliker. Hierdie probleme behoort ons egter nie onnodig pessimisties te stem nie, maar moet eerder as uitdagings beskou word.

Gelukkig is daar die afgelope paar jaar 'n groter bewustheid tov die belangrikheid van ons Vloot. $\mathrm{Vgl}$ bv dat uit die verdedigingsbegroting van R2074 miljoen vir 1980-81, R111 miljoen spesifiek vir maritieme verdediging is, teenoor bv R42 miljoen vir lugverdediging. ${ }^{132}$ Dit is egter ongelukkig ook so dat daar nog hopeloos te veel mense - van alle rasse, gelowe en politieke oortuigings - is by wie daar nog nie belangstelling of begrip is vir militêre aangeleenthede nie, en veral tov seewaartse verdediging.

Wat betref die buiteland sou die ideale situasie wees indien die Weste tot hul sinne sou kom, die waarde van Suid-Afrika - ook tov die maritieme verdediging van die Weste - sal besef, en dan die moed van hul oortuiging aan die dag lê om hulle openlik aan ons kant te skaar. Ons is $\mathrm{nl}$ - of ons dit nou wil weet of nie - deel van die Weste, en moet hulle ook op verdedigingsgebied help, soos wat ons in die verlede ook al ons bereidwilligheid verklaar het.

Hoe wonderlik sou dit nie wees indien ons - in besonder op vlootgebied - alle wapentuig wat ons benodig en nie self kan vervaardig nie, van die Weste kon koop; indien Westerse vlote van ons hawegeriewe gebruik sou maak; ons hawens saam met die nuwe Amerikaanse vlootbasis te Diego Garcia in die Indiese Oseaan deel kon vorm van 'n omvattende verdedigingsnetwerk; en Suid-Afrika en NAVO-land bv gesamentlike vlootoefeninge kon hou.

Intussen moet óns hier aan die suidpunt van Afrika net nóóit vergeet dat wie vrede verlang, hom moet voorberei op oorlog.

* Wrn A. Wessels, BA hon is 'n Nasionale Dienspligtige verbonde aan $\mathrm{HSI}$.

\section{Voetnote}

83. 'n Aantal onderskeibare maar nooit skeibare aspekte wat die maritieme verdediging van Suid-Afrika raak, gaan nou kortliks bespreek word.

84. Daar word te veel eensydige klem geplaas op die Marxistiese gevaar as sou dit die enigste gevaar wees wat ons bedreig. Rooi China is egter ook Kommunisties (Maoisties) en om verskeie redes is die Rooi Chinese meer aanvaarbaar vir die Swartman van Afrika as die (Blanke) Rus. Boonop brei die Rooi Chinese Vloot ook baie uit.

85. Dit moet $\mathrm{nl}$ altyd in gedagte gehou word dat die laaste fase van 'n terroriste- of guerilla-oorlog 'n konvensionele of semikonvensionele fase is.

86. Dan hoef bomdeskundiges nie dmv valskerms, helikopters of skepe gebring te word sou 'n noodsituasie ontstaan nie - vgl bv toe daar 'n bomdreigement ontvang is ivm die luukse passasierskip Queen Elizabeth II.

87. Vgl ook Afdeling V, 3.

88. Wat betref tegniese besonderhede ivm die Saam-klas, vgl Jane's Fighting Ships, 1979-1980, p 255.

89. Wat betref tegniese besonderhede, vgl Ibid, p 602 .

90. Wat betref tegniese besonderhede, vgl Ibid, p 601 .

91. Wat betref tegniese besonderhede, vgl lbid, p 609.

92. Wat betref tegniese besonderhede, vgl Ibid, $p 591$.

93. Wat betref tegniese besonderhede ivm die BAe HS Nimrod maritieme verkenningsvliegtuig, vgl Jane's All the World's Aircraft, 1979-1980, pp 238-239.

94. Wat betref tegniese besonderhede ivm die Westland Lynx, vgl lbid, pp 253-255.

95. Wat betref tegniese besonderhede ivm die Westland Sea King, vgl Ibid, pp 251-252.

96. Wat betref tegniese besonderhede ivm die Panavia Tornado Mk. 1, vgl Ibid, pp 84-97.

97. Wat betref tegniese besonderhede ivm die Dassault-Breguet Atlantic ANG maritieme verkenningsvliegtuie, vgl lbid, p 57.

98. Wat betref tegniese besonderhede ivm die Lockheed P-3 Orion $\mathrm{vgl}$ Ibid, pp 370-371.

99. Wat betref tegniese besonderhede ivm hierdie meerdoelige vaartuie, vgl Jane's Fighting Ships, 1979-1980, p (124).

100. Wat betref tegniese besonderhede ivm die Sauro-klas duikbote, vgl Ibid, p (69)

101. Vgl ook weer eens Afdeling IV.

102. Wat betref tegniese besonderhede ivm die Lupo-klas fregatte, vgl Ibid, p 277. Vgl ook die effens groter Maestrale-klas van 2500 ton.

103. Wat betref tegniese besonderhede ivm die F30-fregatte, vgl Ibid, p 437.

104. Wat betref tegniese besonderhede ivm die Tipe 122-fregatte, vgl Ibid, p 203. 
105. Wat betref tegniese besonderhede ivm die Israelse fregatte en die moontlikheid dat Suid-Afrika van hulle gaan bekom, vgl Ibid, $\mathrm{pp}(114), 264,427$

106. Vgl. Skets 1 .

107. Wat betref tegniese besonderhede ivm die Spruance-klas, vgl Ibid, pp 698-699.

108 Val hic 428 en The Natal Mercury, 24.3.1980, p 9

109. Vir tegniese besonderhede ivm die Augusta A 109- en Agusta-Bell 212-helikopters, vgl Jane's All the World's Aircraft, 1979-1980, pp 113-115.

110. $\mathrm{Vgl}$ Skets 2. Vgl ook die Italiaanse $\mathrm{MV} 400 \mathrm{H}$ missieldraende patrollieboot - Jane's Fighting Ships, 1979-1980, p (51).

111. Vgl Afdeling, $V, 5$.

112. Wat betref tegniese besonderhede ivm die McDonald Phantom II (F-4), vgl Jane's All the World's Aircraft, 1979-1980, pp 381-383.

113. Wat betref tegniese besonderhede ivm die Grumman Tomcat (F-14), vgl Ibid, pp 348-349.

114. Brittanje beskik oor ' $n$ maritieme verkenningsweergawe van hierdie vliegtuig, nl die Coastguarder - vgl, Ibid, pp 229-230.

115. $\mathrm{Vgl}$ dat die Amerikaners self ' $\mathrm{m}$ maritieme verkenningsmodel besit, $\mathrm{nl}$ die $\mathrm{HC}-130 \mathrm{H}-\mathrm{vgl}$ lbid, pp 375-377.

116. Vgl Afdeling II.

117. Vgl Skets 3

118. Vgl Skets 4

119. Vgl Jane's Fighting Ships, 1979-1980, p (95).

120. Blykbaar werk Swartmanne tans slegs as dokwerkpersoneel in die Vloot. Dit moet natuurlik in gedagte gehou word dat die Indiëren Bruinmense ' $n$ noue verbondenheid met die see het, iets wat moontlik by die meeste Swartmense ontbreek.

121. Vgl dat daar wel in Junie/Julie 1980 vier Wes-Duitse oorlogskepe op ' $n$ vlagvertoonreis aan die Ooskus van Afrika is. $\mathrm{Vgl} \mathrm{ook} \mathrm{dat}$ Frankryk op 'n permanente grondslag oorlogskepe in die Indiese Oseaan ontplooi.

122. Moontlik beleef ons tans die post-Kouer Oorlog-era.

123. Vgl Fourie, op cit, $p 65$.

124. The Natal Mercury, 27.3.1980, p 1.

\section{Bronnelys}

Chant, C. (red) - The World's Air Forces. David and Charles, Newton Abbott, London sj.

Du Toit, A. K. - Ships of the South African Navy. SA Boating Publications, Kaapstad, 1976.

Fourie, D. - "Maritieme Strategie" in Lantern: tydskrif vir kennis en kultuur, vol XXII, nr 2, Des 1972, pp 64-73.

Goosen, J. C. (hoofsamesteller) - South African Navy: the first fifty years. W. J. Flesch, Kaapstad en Johannesburg, 1973.

Grütter, W. - 'n Naam wat Seevaarders eer: 'n geskiedenis van die opleidingskip Generaal Botha. 1973.

Jane's all the World's Aircraft, 1979-1980. Jane's Yearbooks, Londen, 1979.

Jane's Fighting Ships, 1979-1980. Jane's Yearbooks, Londen, 1979. The Natal Mercury, 24.3.1980 en 27.3.1980.

Standard Encyclopaedia of Southern Africa, vols 8, 9 en 10. Nasou, Kaapstad, 1974. 